Webology, Volume 17, Number 1, June, 2020

\begin{tabular}{|l|l|l|l|}
\hline Home & Table of Contents & Titles \& Subject Index & Authors Index \\
\hline
\end{tabular}

\title{
Effect of Green Marketing Instruments and Behavior Processes of Consumers on Purchase and Use of E-books
}

\author{
Atefeh Farzin \\ Master of Information Management, Department of Knowledge and Information Science, Faculty of \\ Management, University of Tehran, Tehran, Iran. ORCID: 0000-0002-6008-1872. \\ E-mail: atefehfarzin73@ut.ac.ir
}

\section{Saba Yousefi*}

*Corresponding author, Master of Information Management, Department of Knowledge and Information Science, Faculty of Management, University of Tehran, Tehran, Iran. ORCID: 0000-0003-1181-9700. E-mail: saba.yousefi@ut.ac.ir

\section{Sepideh Amieheidari}

Master of Information Management, Department of Knowledge and Information Science, Faculty of Management, University of Tehran, Tehran, Iran. E-mail: sepideh.amirheidari@ yahoo.com

\section{Alireza Noruzi}

Associate Professor, Department of Knowledge and Information Science, Faculty of Management, University of Tehran, Tehran, Iran. ORCID: 0000-0003-0877-1566. E-mail: noruzi@ut.ac.ir

Received January 15, 2020; Accepted June 20, 2020

\section{Abstract}

The present study aims to investigate the effect of green marketing instruments and to understand the behavior of consumers in the purchase and use of e-books. The environmental label is one of the tools of green marketing that can be used in the primary pages of e-books to show being an environmentalist. This applied study is a survey-descriptive one in terms of collecting data. The population of the current study consists of 65 postgraduate students of the Department of Knowledge and Information Science of the University of Tehran in 2019, which 55 of them were selected by simple random sampling method using the Cochran's sample size formula with the confidence level of 0.05 . A researcher-made questionnaire including 34 questions has been used 
to collect data. The Statistical Package for Social Sciences (SPSS) software was used to analyze and describe the data. The results showed that among the six measured parameters (i.e., 1. users' awareness of the environment; 2. users' environmental advocacy; 3. environmental advertising; 4. users' attitudes toward the environment; 5. users' purchase intention; and 6. environmental label), there is a meaningful and positive relationship between the four first above-mentioned parameters respectively and there is no meaningful relationship between fifth and sixth parameters. Based on the results of the present study, libraries, publishers and distributors of ebooks are recommended to promote the environmental advocacy and green marketing to achieve their purpose in increasing the digital reading level of the country and to encourage users to choose the digital reading at a low cost, and also, help protect the environment and stop cutting down trees. Based on the results of the present research, we suggest to librarians and publishers of e-books to pay attention to users' awareness of the environment, users' environmental advocacy, environmental advertising, and users' attitudes toward the environment respectively.

\section{Keywords}

Green marketing; Consumer behavior; E-books; Digital libraries; Green marketing

\section{Introduction}

Public awareness has been enhanced in the environmental issues especially air pollution due to the increase of environmental conflicts in the world and the role of mass media and nongovernmental organizations in notifying society (Mansouri, 2011). During recent decades, environmentalist groups have promoted exponential growth of environmental news and activities and have focused on environmental damages (Thogerson \& Grunert, 1997). International studies have shown that cutting down trees has a direct and significant relationship with environmental damages and air pollution and this issue has made consumers modify their consumption and purchase patterns and act more conservative about the products they have bought and revised their consumption behavior (Papadolous et al., 2010).

Due to the importance of the environment protection, cultural and commercial organizations have attempted to balance between consumers' usage and purchase behavior and environmental protections. Green marketing is a revolution in the social marketing approach that has been entered into the world of marketing. Green marketing contains all activities in the creation and facilitation of exchanges to meet human needs and demands in a way that has the least harmful and destructive effects on the environment. Green marketing introduced and discussed for the first time in the 1980s (Grant, 2008). Regarding the awareness of society about the environmental issues, organizations and companies pay more attention to green marketing strategies and try to ensure that their services and products are compatible with the environment 
and safe to use (Groening, Sarkis \& Zhu, 2018). This would mean a greater reliance on natural materials or products that are compatible with the environment.

Green marketing strategies help digital libraries and information centers to perform their duties, while reducing the environmental pollution, preserving natural resources, preventing from cutting down trees to make paper and improving environmental performance (Pashootanizadeh \& Salimian Rizi, 2018). Thus, libraries, as an important cultural and social organization, can have a significant role in the promotion of environmental protections.

According to the environment reports, each Iranians consumes an average of 13 kilograms of paper annually which is totally 910 million kilograms. Therefore, it takes approximately 17 trees to make one ton of printing paper; and 15 million trees are annually cut for the production of paper in Iran (Molana, 2018). On the other hand, with day-to-day advancements of technology and creation of necessary sub-structures to make e-books, libraries have used this opportunity to prevent from cutting down trees and be effective in the protection of the environment by digitizing almost all research material which was traditionally published on paper, for example, books, journals, theses, and other information sources. In other words, digitizing information sources is one of the ways to protect the environment by libraries and information centers.

An electronic book (e-book) is a book which is produced and published in electronic format for reading on a specialized device or computer screen, and is not printed on paper. Oxford Learners Dictionaries (2020) defined e-book as: "a book that is displayed on a computer screen or on an electronic device that is held in the hand, instead of being printed on paper." Libraries can prepare an electronic version of their books to provide digital services to their users. Digital publishers in collaboration with authors and librarians can create e-books and facilitate digital reading, encouraging interaction between writers and readers. Digital reading communities are an important resource for publishers and writers. They are becoming an important part of electronic publishing, with readers forming discussion groups and friendships online.

If the culture of reading e-books considered important by libraries and publishers and these two organizations be able to persuade readers and book purchasers in purchasing and using e-books, a huge improvement will take place in the protection of the environment. Green marketing consists of all designed activities to create and implement each exchange to fulfill the needs and demands of individuals with minimum damage to the environment (Manafi, 2016). Based on existing theories, green marketing tools comprised of the environmental label, brand, and environmental advertising. Such tools can enhance awareness about features of green products and accordingly help users and purchasers use and purchase environmental products. Using this policy will have an essential role in purchasing environmental products and will reduce negative effects on the environment (Rahbar \& Abdolvahid, 2011). 
E-books publishers and distributors can use green marketing strategies in the promotion of the environmental protection culture, encouraging readers and purchasers to buy e-books. The environmental label is one of the tools of green marketing that can be used in the primary pages of e-books to indicate being an environmentalist. It demonstrates that the publisher and the author of an e-book are environmental advocates. Environmental labels as environmental advocacy can be used as a sign for users to pick environmentalist products and help producers distinguish their products, positioning and transfer their being environmentalist messages (Manafi, 2016). Moreover, e-books publishers and distributors can introduce themselves as a specific brand to environmentalists, through this way they can use an environmental brand as another green marketing tool. An environmental brand is a name, sign, symbol, or design of products that are harmless to the environment. Through the brand, users can distinguish between green products and non-green ones. Environmental advertising as the third green marketing tool cab be used by libraries and publishers of e-books. Environmental advertising is a claim about being environmentalist and having an environmentalist product.

According to the theory of Paco, Raposo and Filho (2009) factors such as awareness, attitude, purchase intention and users' status of being environmentalists are influential on the behavior of users. During previous decades there has been a considerable growth in environmental awareness across the world and behavioral literature has been demonstrative of a positive relationship between knowledge and behavior. Moreover, so many studies show that environmental knowledge and awareness has a direct relationship with many behaviors of a consumer. However, environmental awareness of this study's population must be measured.

Environmental attitudes are a collection of belief, emotional and practical wills of an individual influential on issues and measures related to the environment (Schultz et al., 2007) and are defined as a personal value judgment of the environmental protection (Lee, 2008). Due to the effect of environmental attitudes of users on their purchasing and using e-books, this parameter must be measured in the study. It is obvious that users' purchase intention and their need effect on purchasing and using e-books. Also, another factor which helps green marketing concept to influence users' behavior is the status of being environmentalist. Being an environmentalist may be the result of internal or external factors (Polonsky \& Rosenberger, 2001).

Iran has remarkable strengths and opportunities in the green economy, eco-innovation, and in the environmental protection. Protecting this invaluable treasure is related to people's attempts, who pay attention to green and environmental marketing programs. Now the question is, how influential are producers and distributors of e-books and which services provide to internalize the behavior of green purchase. On the other hand, how users and purchasers of books pay attention to e-books and consequently protecting the environment. Therefore, the present study aims at investigating the effect of green marketing tools and behavior processes of consumers on the purchase and use of e-books. The main objectives of the current research are: 
1. to determine the effect of users' awareness of the environment, users' purchase intention, and users' attitudes about the environment on purchasing and using e-books.

2. to determine the effect of environmental advertising, environmental label, and users' environmental advocacy on purchasing and using e-books.

\section{Research Questions}

1. How effective are users' awareness of the environment on their purchasing and using e-books?

2. How effective are users' purchase intention on their purchasing and using e-books?

3. How effective are users' attitudes toward the environment on their purchasing and using ebooks?

4. How effective is the environmental advertising on users' purchasing and using e-books?

5. How effective is the environmental label on users' purchasing and using e-books?

6. How effective are users' environmental advocacy on their purchasing and using e-books?

\section{Literature Review}

In the subjective field of green marketing, various studies have been conducted on different organizations and products. A few studies have been done on green marketing in libraries in the field of library and information science. However, green libraries must spend a significant part of their time and energy to optimize the use of paper. But no studies have been conducted on ebooks and their effects on the environment. However, few studies concerning this field have been reported and many problems remain still unsolved.

Nadafi, Noori, Nabizadeh and Nazok (2008) in a research entitled "Green management system in Iran National Library" have investigated different sources of water, energy, paper, and solid wastes in Iran National Library and also, consumption management of these sources to represent management approaches. The research findings revealed that with performing green management system in Iran National Library, there is a possibility to optimal use of these resources which helps the environmental protection and establish green culture through staff's awareness enhancement.

Ranaei Kordshuli and Allahyari Buzanjani (2012) in a study entitled "Investigating the mixed effect of green marketing on consumers' decision to green purchasing (consumers of Pegah Dairy Company's products in Shiraz)" have found out that each of mixed advertising, distribution and cost dimensions of green marketing have a positive and meaningful effect on consumer's green purchase while the green product has a negative and insignificant effect on consumer's green purchase.

Mohammadian and Bakhshandeh (2014) in a paper entitled "Investigation of influential factors on consumers' attitude and green purchase intention" have concluded that attitudes towards 
green products has a positive and meaningful effect on purchase intention of green products and payment intention and perceived necessity variables considered as moderator variables, respectively.

Bahrainizadeh and Rezaei (2016) in a study entitled "Meta-analysis and identification of influential factors on decision making behavior of consumers'green purchase" have investigated to determine the factors that have the most effect on green purchase behavior, results of the metaanalysis showed that environmental concern, social effects, perceived effectiveness, social responsibility, personal understanding concern, perception of the importance of the environmental issues and intention to purchase green products have the most effect on green purchase behavior in different studies.

Ghorbani, Babolhavaeji and Noushinfard (2017) in a research entitled "Sustainable management indicators for green libraries: Qualitative research" have compiled sustainable management indices in Iran libraries to achieve green library and have figured out that libraries need a pattern of sustainable management to achieve sustainability indices and moving towards green libraries.

Pashootanizadeh and Salimian Rizi (2018) in a paper entitled "Determining the importance of environmental concerns, social plans for green marketing and green buying behavior in the public libraries of Isfahan" have studied the role of libraries as a cultural and social organization in environmental issues and results showed that many of the environmental crisis have roots in cultural issues and since public libraries are cultural and influential institutes, activities in such organization which is permanently evolving to respond informational demands make librarians familiar with cultural issues and recent events in the world, so they will try to enhance other people's awareness about the environmental issues and finally help green products purchasing and sustainable development.

Suplico (2009) in a research entitled "Impact of green marketing on the students' purchase decision" in Philippine University stated that consumers are responsible for the environmental issues and take part in this process by purchasing green products. She has shown that university students consider green marketing as the fifth index after demand, price, preference of special product, and budget.

Oyelude and Alabi (2013) in a survey entitled "Greening: pluses and minuses of Nigerian libraries in promoting environmental sustainability" conducted with an online questionnaire and observation methods in data collecting, 31 online respondents working in academic libraries, 6 individuals working in public libraries, 3 individuals working in private libraries and 1 working in the national library have shown that Nigerian librarians have low awareness about the environmental issues; but there is motivation in green policies and activities. 
Kraljević and Lukačić (2015) in a paper entitled "Project Green Library in Croatia" aimed at investigating Croatian librarians' interest to contribute in green library proposal have found out that librarians have been interested in taking part in this proposal and their awareness of the environmental issues have been enhancing and also, have been interested in participating in the development and dealing with environmental issues.

Reviewing studies in the field of green marketing, consumers' behavior in green purchasing and influential factors on them have revealed that some studies have been conducted in relation to these concepts in different organizations except e-books in Iran. Therefore, it is possible to observe studies that have focused on concept, function, importance, and parameters of the green library more limited in Iran and wider abroad. Although e-books publishers and distributors can have a significant role in the formation of green marketing and behavior of green purchase, such a study has not been conducted so far.

\section{Materials and Methods}

The present study is applied in terms of purpose and survey-descriptive in terms of data collecting. The research-made questionnaire of Manafi (2016) and Kim's (1995) questionnaire were used as the main instrument of data collection in this study. Along with more adaptation with the current study subject and purpose, extra items have been revised. To measure opinions 5 points Likert Scale (1. strongly disagree, 2. agree, 3. neutral, 4. disagree and 5. strongly disagree) has been used with 34 questions that 6 questions related to user's awareness, 8 questions related to users' purchase intention, 7 questions related to users' attitudes toward the environment, 3 questions related to the environmental advertising for e-books, 3 questions related to the environmental label for e-books and 7 questions related to the status of being environmentalist.

The statistical population of the current study consists of all 65 postgraduate students of the Department of Knowledge and Information Science of the University of Tehran in 2019. A printed and an online questionnaire were used. Based on the convenient sampling method, postgraduate students of the Department of Knowledge and Information Science of the University of Tehran have been studied which 55 of them selected through Cochran random sampling to determine the number of respondents as study samples.

All studies have error probability in terms of data collecting, this study also is not an exception, so besides descriptive statistical tests, inferential statistics were also used. To measure the study data normality the Kolmogorov-Smirnov test and to measure meaningfulness of research questions on sample, the t-test were used. First, a summary of general characteristics of respondents with the tables of frequency distribution of green marketing instruments scores and processes of consumer's behavior about the purchase and use of e-books has been described then 
through the use of descriptive statistics measures of central tendency (average) and distribution (variance and standard deviation) have been represented.

\section{Results}

Here through the illustration of respondents' frequency distribution table based on the fundamental questions of the questionnaire, a summary of the general characteristics of respondents are represented and then their statuses are investigated. Table 1 shows that 55 samples made up of 30 males (54.5\%) and 25 females (45.5\%). Table 1 indicates that the age range of 23 individuals (45.1\%) is between 21 and 30, 21 individuals (41.2\%) between 31 and 40 , and 7 individuals $(13.7 \%$ ) between 41 and 50 years old.

Table1. Respondents' frequency distribution based on gender

\begin{tabular}{|c|c|c|}
\hline Gender & Frequency & Percent \\
\hline Male & 30 & 54.5 \\
\hline Female & 25 & 45.5 \\
\hline Total & 55 & 100 \\
\hline
\end{tabular}

Table 2. Respondents' frequency distribution based on age

\begin{tabular}{|c|c|c|}
\hline Age & Frequency & Percent \\
\hline 21 to 30 & 23 & 45.1 \\
\hline 31 to 40 & 21 & 41.2 \\
\hline 41 to 50 & 7 & 13.7 \\
\hline Total & 55 & 100 \\
\hline
\end{tabular}

Table 3. Descriptive indices (central and dispersion) of green marketing instruments, consumer's behavior processes in purchasing and using e-books scores

\begin{tabular}{|l|c|c|c|}
\hline $\begin{array}{c}\text { Green marketing instruments and consumer's } \\
\text { behavior processes }\end{array}$ & Average & Variance & $\begin{array}{c}\text { Standard } \\
\text { Deviation (SD) }\end{array}$ \\
\hline Users' awareness of the environment & 23.51 & 20.477 & 4.525 \\
\hline Users' purchasing intention & 23.11 & 64.284 & 8.018 \\
\hline Users' attitudes toward the environment & 23.25 & 33.638 & 5.800 \\
\hline Environmental advertising & 10.42 & 8.470 & 2.910 \\
\hline Environmental label & 9.13 & 9.076 & 3.013 \\
\hline Users' environmental advocacy & 24.53 & 38.698 & 6.221 \\
\hline
\end{tabular}

In Table 3, descriptive indices (central and dispersion) of six parameters of green marketing, consumer's behavior processes in purchasing and using e-books have been determined. To investigate questions, first, it is necessary to measure an assumption parametric test, that is data normality in the level of meaningfulness of 0.05 . 
Table 4. Kolmogorov-Smirnov test to measure data normality

\begin{tabular}{|l|c|c|}
\hline \multicolumn{1}{|c|}{ Study variables } & P-value & Test \\
\hline & (two tailed) & Kolmogorov-Smirnov \\
\hline Users' awareness of the environment & 0.096 & 0.110 \\
\hline Users' purchasing intention & 0.008 & 0.141 \\
\hline Users' attitudes toward the environment & 0.071 & 0.114 \\
\hline Environmental advertising & 0.032 & 0.125 \\
\hline Environmental label & 0.011 & 0.138 \\
\hline Users' environmental advocacy & 0.200 & 0.073 \\
\hline
\end{tabular}

According to the results of the Kolmogorov-Smirnov test in Table 4, meaningfulness is more than 0.05 in most variables. So it is concluded that variables distribution is normal, so it is possible to use parametric tests.

First question: How effective are users' awareness of the environment tool on their purchasing and using e-books?

Table 5. One sample t-test statistics (sample users and users of real society)

\begin{tabular}{|c|c|c|c|c|c|c|}
\hline \multicolumn{7}{|c|}{ One sample t-test } \\
\hline \multicolumn{2}{|c|}{$\begin{array}{c}\text { Confidence interval in level } \\
\text { of } 95 \%\end{array}$} & \multirow{2}{*}{ P-value } & \multirow{2}{*}{$\begin{array}{l}\text { Averages } \\
\text { difference }\end{array}$} & \multirow{2}{*}{$\begin{array}{l}\text { Society } \\
\text { average }\end{array}$} & \multirow{2}{*}{$\begin{array}{l}\text { Sample } \\
\text { average }\end{array}$} & \multirow{2}{*}{$\mathrm{t}$} \\
\hline High level & Low level & & & & & \\
\hline 6.73 & 4.29 & 0.000 & 5.51 & 18.00 & 23.51 & 9.029 \\
\hline
\end{tabular}

Sample users (postgraduate students of the Department of Knowledge and Information Science) Society (users of real society)

Table 5 indicates that p-value of one sample t-test is 0.000 which is less than 0.05 , so the difference between variables is meaningful and the research hypothesis is confirmed. Hence it is concluded that users' awareness of the environment has a positive and meaningful effect on purchasing and using e-books. Also, the degree of effect is 5.51 more than the average of real society which is meaningful statistically.

Second question: How effective are users' purchase intention on their purchasing and using ebooks?

Table 6. One sample t-test statistics (sample users and users of real society)

\begin{tabular}{|c|c|c|c|c|c|c|}
\hline \multicolumn{2}{|c|}{ One sample t-test } \\
\cline { 1 - 5 } $\begin{array}{c}\text { Confidence interval in level } \\
\text { of 95\% }\end{array}$ & \multirow{2}{*}{ P-value } & $\begin{array}{c}\text { Averages } \\
\text { difference }\end{array}$ & $\begin{array}{c}\text { Society } \\
\text { average }\end{array}$ & $\begin{array}{c}\text { Sample } \\
\text { average }\end{array}$ & $\mathrm{t}$ \\
\cline { 1 - 5 } High level & Low level & 0.414 & -0.89 & 24.00 & 23.11 & -0.824 \\
\hline 1.28 & -3.06 & 0.49 &
\end{tabular}

Table 6 shows that $\mathrm{p}$-value of one sample t-test is 0.414 which is more than 0.05 , so the difference between averages is not meaningful and the research hypothesis is not confirmed. 
Hence, it is concluded that users' purchasing intention has no positive and meaningful effect on purchasing and using e-books. Also, the degree of effect is slight and negative and 0.89 less than the average of real society that is not meaningful statistically.

Third question: How effective are users' attitudes toward the environment on their purchasing and using e-books?

Table 7. One sample t-test statistics (sample users and users of real society)

\begin{tabular}{|c|c|c|c|c|c|c|}
\hline \multicolumn{7}{|c|}{ One sample t-test } \\
\hline \multicolumn{2}{|c|}{$\begin{array}{c}\text { Confidence interval in } \\
\text { level of } 95 \%\end{array}$} & \multirow{2}{*}{ P-value } & \multirow{2}{*}{$\begin{array}{l}\text { Averages } \\
\text { difference }\end{array}$} & \multirow{2}{*}{$\begin{array}{l}\text { Society } \\
\text { average }\end{array}$} & \multirow{2}{*}{$\begin{array}{l}\text { Sample } \\
\text { average }\end{array}$} & \multirow{2}{*}{$\mathrm{t}$} \\
\hline High level & Low level & & & & & \\
\hline 3.82 & 0.69 & 0.006 & 2.25 & 21.00 & 23.25 & 2.883 \\
\hline
\end{tabular}

Table 7 reveals that p-value of one sample t-test is 0.006 which is less than 0.05 , so the difference between averages is meaningful and the research hypothesis is confirmed. Hence it is concluded that users' attitudes toward the environment has a positive and meaningful effect on purchasing and using e-books. Also, the degree of effect is 2.25 more than the average of real society that is meaningful statistically.

Fourth question: How effective is the environmental advertising tool on users' purchasing and using e-books?

Table 8. One sample t-test statistics (sample users and users of real society)

\begin{tabular}{|c|c|c|c|c|c|c|}
\hline \multicolumn{2}{|c|}{ One sample t-test } \\
\cline { 1 - 2 } $\begin{array}{c}\text { Confidence interval in } \\
\text { level of } 95 \%\end{array}$ & \multirow{2}{*}{ P-value } & $\begin{array}{c}\text { Averages } \\
\text { difference }\end{array}$ & $\begin{array}{c}\text { Society } \\
\text { average }\end{array}$ & $\begin{array}{c}\text { Sample } \\
\text { average }\end{array}$ & $\mathrm{t}$ \\
\cline { 1 - 2 } High level & Low level & 0.001 & 1.42 & 9.00 & 10.42 & 3.614 \\
\hline 2.20 & 0.63 & 0.42 &
\end{tabular}

According to Table 8, p-value of one sample t-test is 0.001 which is less than 0.05 , so the difference between averages is meaningful and the research hypothesis is confirmed. Hence it is concluded that environmental advertising has a positive and meaningful effect on purchasing and using e-books. Also, the degree of effect is 1.42 more than the average of real society that is meaningful statistically.

Fifth question: How effective is the environmental label on users' purchasing and using $e$ books?

Table 9. One sample t-test statistics (sample users and users of real society)

\begin{tabular}{|c|c|c|c|c|c|c|}
\hline \multicolumn{7}{|c|}{ One sample t-test } \\
\hline \multicolumn{2}{|c|}{$\begin{array}{c}\text { Confidence interval in } \\
\text { level of } 95 \%\end{array}$} & \multirow[t]{2}{*}{$\mathrm{P}$-value } & \multirow{2}{*}{$\begin{array}{l}\text { Averages } \\
\text { difference }\end{array}$} & \multirow{2}{*}{$\begin{array}{l}\text { Society } \\
\text { average }\end{array}$} & \multirow{2}{*}{$\begin{array}{l}\text { Sample } \\
\text { average }\end{array}$} & \multirow{2}{*}{$\mathrm{t}$} \\
\hline High level & Low level & & & & & \\
\hline 0.94 & -0.69 & 0.755 & 0.13 & 9.00 & 9.13 & 0.313 \\
\hline
\end{tabular}


According to Table 9, p-value of one sample t-test is 0.775 which is more than 0.05 , so the difference between averages is not meaningful and the research hypothesis is not confirmed. Hence it is concluded that environmental label has no positive and meaningful effect on purchasing and using e-books. Also, the degree of effect is slight and positive and 0.13 more than the average of real society that is not meaningful statistically.

Sixth question: How effective are users' environmental advocacy on their purchasing and using e-books?

Table 10. One sample t-test statistics (sample users and users of real society)

\begin{tabular}{|c|c|c|c|c|c|c|}
\hline \multicolumn{2}{|c|}{ One sample t-test } \\
\cline { 1 - 5 } $\begin{array}{c}\text { Confidence interval in } \\
\text { level of } 95 \%\end{array}$ & \multirow{2}{*}{ P-value } & $\begin{array}{c}\text { Averages } \\
\text { difference }\end{array}$ & $\begin{array}{c}\text { Society } \\
\text { average }\end{array}$ & $\begin{array}{c}\text { Sample } \\
\text { average }\end{array}$ & $\mathrm{t}$ \\
\cline { 1 - 6 } High level & Low level & 0.000 & 3.53 & 21.00 & 24.53 & 4.205 \\
\hline 5.21 & 1.85 & 0.53 &
\end{tabular}

Table 10 indicates that p-value of one sample t-test is 0.000 which is less than 0.05 , so the difference between averages is meaningful and the research hypothesis is confirmed. Hence it is concluded that users' environmental advocacy has a positive and meaningful effect on purchasing and using e-books. Also, the degree of effect is 3.53 more than the average of real society that is meaningful statistically.

\section{Discussion and Conclusion}

To achieve the objective of the current study, that is "investigating the effect of green marketing instruments and processes of consumer's behavior on purchasing and using e-books", main parameters of the study are: users' awareness of the environment, users' environmental advocacy, environmental advertising, users' attitudes toward the environment, users' purchase intention and environmental label. According to results of one sample t-test with the confidence of 95 percent resulted from respondents' view, in four parameters of study the research hypotheses have been confirmed and in respondents' point of view: users' awareness of the environment, users' environmental advocacy, environmental advertising, users' attitudes toward the environment are important respectively, and there is no meaningful and positive relationship for two parameters of users' purchase intention and environmental label.

So it can be concluded that users' awareness of the environment's importance and preventing from damage through books is the main reason that encourages users to use and purchase ebooks, these findings are in line with the study of Manrai et al. (1997) who found that individuals' awareness of the environment may lead to purchasing green products and also, findings of Mustafa's study (2009) who showed that consumers' awareness and concern about the environmental issues and their intention to purchase green products are among the significant reasons to make consumers' green behavior but these results are not consistent with the results of 
the study by Haghighi and Khalil (2011) that figured out although consumers are sensitive to environmental issues, this sensitivity and concern does not necessarily lead to green purchase behavior. One possible reason for this discrepancy may be the lack of users' intention to buy or the high price of green products. To answer this problem, Bahrainizadeh and Rezaei (2016) concluded that environmental concern, social effects, perceived effectiveness, social responsibility, personal understanding concern, perception of the importance of the environmental issues and intention to purchase green products have the most effect on green purchase behavior in different studies.

Another parameter in the present study is the environmental advertising which has a positive effect on enhancing purchasing and using e-books, this result is consistent with Ranaei Kordshuli and Allahyari Bouzjani (2012) that have argued that each of mixed dimensions of advertising, distribution and the cost of green marketing have a positive and meaningful effect on consumers' purchase, although it is not consistent with the result that green product has a negative and not meaningful effect on consumers' green purchase. Thus, libraries, publishers and distributors of ebooks are recommended to use environmental advertising to achieve their goals.

On one hand, findings show that users' purchase intention for purchasing and using e-books could not be effective and this result is not consistent with the study conducted by Mohammadian and Bakhshandeh (2014) who concluded that the attitudes towards green products have a positive and meaningful effect on purchase intention of green products. Low per capita of reading and not prioritizing reading in our country may be among the reasons for this inconsistency. Also, using environmental labels for e-books is not effective in encouraging users to use and purchase e-books. It seems that there is no national environmental label to show books' status of not damaging the environment, which makes a positive and meaningful relationship for this parameter.

Based on the results of the present study, libraries, publishers and distributors of e-books are recommended to promote the environmental advocacy and green marketing to achieve their purpose in increasing the digital reading level of the country and to encourage users to choose the digital reading at a low cost, and also, help protect the environment and stop cutting down trees. Based on the results of the present research, we suggest to librarians and publishers of ebooks to pay attention to users' awareness of the environment, users' environmental advocacy, environmental advertising, and users' attitudes toward the environment respectively.

\section{Recommendations}

The results of this study suggest that libraries, publishers and distributors of e-books would digitize books and should introduce e-books and advantages of using e-books, e-books availability, prevention from trees damage and a positive movement towards the environment protection, encouraging book readers to use and purchase e-books. Also, it is possible to invite 
environmentalists to give lectures so that users believe that they can help protect the environment and stop cutting down trees.

\section{References}

Bahrainizadeh, M., \& Rezaei, B. (2016). Meta-analysis and identification of influential factors on decision making behavior of consumers' green purchase. Management Research in Iran, 20(2), 21 48. (in Persian).

Do Paço, A. M., Barata Raposo, M. L., \& Filho, W. L. (2009). Identifying the green consumer: A segmentation study. Journal of Targeting, Measurement and Analysis for Marketing, 17(1), 17-25.

Ghorbani, M., Babolhavaeji, F., \& Noushinfard, F. (2017). Sustainable management indices for green libraries: Qualitative Research. Journal of National Studies on Librarianship and Information Organization, 28(1), 47-67. (in Persian).

Grant, J. (2008). Green marketing. Strategic direction, 24(6), 25-27.

Groening, C., Sarkis, J., \& Zhu, Q. (2018). Green marketing consumer-level theory review: A compendium of applied theories and further research directions. Journal of Cleaner Production, $172,1848-1866$.

Haghighi, M., \& Khalili, M. (2011). Investigation of Green Marketing Position of in Consumer's Buying behavior. Organizational Culture Management, 9(2), 83-102. (in Persian).

Kim, H.-S. (1995). Consumer response toward apparel products in advertisements containing environmental claims. Doctoral dissertation, Department of Textiles and Clothing, Iowa State University.

Komakech, R. A., \& Magara, E. (2018). Managing collaboration between the author and publisher for career growth in Africa. In Building Capacity for Sustainable Academic and Non-fiction Authorship in Africa. Uganda: Uganda Textbook Academic and Non-fiction Authors' Association (UTANA).

Kraljević, I., \& Lukačić, P. (2015). Project Green Library in Croatia. IFLA WLIC, Cape Town, 2015. Retrieved January 20, 2020, from http://library.ifla.org/1208/1/095-kraljevic-en.doc.pdf

Lee, K. (2008), Opportunities for Green Marketing: Young Consumer, Marketing Intelligence \& Planning, 26(6), PP: 573-586.

Manafi, A. (2016). The effects of the green marketing s'tools on consumer behaviour in throw-away crockery. Master Thesis, University of Tehran, Faculty of Management, Department of Business Management. (in Persian).

Manrai, L. A., Manrai, A. K., Lascu, D. N., \& Ryans Jr, J. K. (1997). How green-claim strength and country disposition affect product evaluation and company image. Psychology \& Marketing, 14(5), 511-537.

Mansouri, N. (2011). Environmental pollutions air, water, waste, noise. Tehran, Arad Book. (in Persian)

Mohammadian, M., \& Bakhshandeh, G. (2015). Investigation of influential factors on consumers' attitude and green purchase intention. Management Studies in Development and Evolution, 23(3), 39-68. (in Persian). 
Molana, Y. (2018). Maskan Bank builds "green house"! Fars News, 13 November 2018. (in Persian)

Mostafa, M. M. (2009). Shades of green: A psychographic segmentation of the green consumer in Kuwait using self-organizing maps. Expert Systems with Applications, 36(8), 11030-11038.

Nadafi, K., Noori, G., Nabizadeh, R., \& Nazok, S. (2008). Green management system in Iran National Library . Journal of Environmental Science and Technology, 10(4), 262-269. (in Persian).

Oxford Learners Dictionaries (2020). Oxford University Press. Retrieved January 20, 2020, from https://www.oxfordlearnersdictionaries.com/definition/american_english/e-book

Oyelude, A. A., \& Alabi, A. O. (2013). Greening: Pluses and minuses of Nigerian libraries in promoting environmental sustainability. Retrieved January 20, 2020, from http://library.ifla.org/133/1/115boyelude-en.pdf

Papadopoulos, I., Karagouni, G., Trigkas, M., \& Platogianni, E. (2010). Green Marketing: the Case of Greece in Certified and Sustainably Managed Timber Products. Euro Med Journal of Business. 5(2), 166-190.

Pashootanizadeh, M., \& Salimian Rizi, M. (2018). Determining the importance of environmental concerns, social plans for green marketing and green buying behavior in the public libraries of Isfahan. Library and Information Science Research, 8(1), 267-285. (in Persian) https://infosci.um.ac.ir/index.php/riis/article/view/66637

Polonsky, M. J., \& Rosenberger III, P. J. (2001). Reevaluating green marketing: a strategic approach. Business Horizons, 44(5), 21-30.

Rahbar, E., \& Abdul Wahid, N. (2011). Investigation of green marketing tools' effect on consumers' purchase behavior. Business Strategy Series, 12(2), 73-83.

Ranaei Kordshouli, H., \& Allahyari Bouzanjani, A. (2012). Investigating the mixed effect of green marketing on consumers' decision to green purchasing (consumers of Pegah Dairy Company's products in Shiraz). Journal of New Marketing Research, 2(2), 165-180. (in Persian).

Schultz, P. W., Nolan, J. M., Cialdini, R. B., Goldstein, N. J., \& Griskevicius, V. (2007). The constructive, destructive, and reconstructive power of social norms. Psychological Science, 18 (5), 429-434.

Suplico, L. T. (2009). Impact of green marketing on the students' purchase decision. Journal of International Business Research, 8(2), 71.

Thogerson, J., \& Grunert-Beckmann, S. C. (1997). Values and attitude formation towards emerging attitude objects: From recycling to general waste minimizing behavior. Advances in Consumer Research, 24, 182-189.

\section{Bibliographic information of this paper for citing:}

Farzin, A., Yousefi, S., Amieheidari, S., \& Noruzi, A. (2020). "Investigating the effect of green marketing instruments and behavior processes of consumers on purchase and use of e-books." Webology, 17(1), Article 217. Available at: http://www.webology.org/2020/v17n1/a217.pdf

Copyright $\odot$ 2020, Atefeh Farzin, Saba Yousefi, Sepideh Amieheidari and Alireza Noruzi. 